\title{
CLINICAL AND SOCIODEMOGRAPHIC PROFILE OF TYPE 2 DIABETES MELLITUS IN RURAL POPULATION OF VINDHYA REGION
}

\author{
Praveen Kumar Baghel ${ }^{1}$, Keshav Singh ${ }^{2}$, Umesh Pratap Singh ${ }^{3}$
}

1Professor, Department of Medicine, S.S Medical College and S.G.M Hospital, Rewa, (M. P.).

${ }^{2}$ Assistant Professor, Department of Medicine, S.S Medical College and S.G.M Hospital, Rewa, (M. P.).

${ }^{3}$ Resident, Department of Medicine, S.S Medical College and S.G.M Hospital, Rewa, (M. P.).

\section{BACKGROUND}

ABSTRACT

Diabetes Mellitus (DM) is a major epidemic of this century. The prevalence of Type 2 Diabetes Mellitus (T2DM) is $11 \%$ in urban areas, while it is 3\% - 9\% in rural areas. The prevalence of diabetes and its complications is now rapidly increasing in India among the poor in the urban slum dwellers, the middle class and even in the rural areas. This is due to changes in lifestyle and dietary habits associated with urbanisation and globalisation.

\section{MATERIALS AND METHODS}

500 type 2 diabetic patients from rural area of Vindhya region were included in the study. A detailed history and thorough clinical examination was done. Anthropometric measurements were recorded.

\section{RESULTS}

Out of 500 patients, 277 (55.4\%) were males and 223 (44.6\%) were females. Most of the patients, 303 (66.6\%) were in the age group of 41 - 60 years with mean age of $57 \mathrm{yrs}$. In present study $71.8 \%$ patients were addicted to tobacco chewing, $28 \%$ were addicted to smoking and $11.2 \%$ were addicted to alcohol. $37.4 \%$ patients have positive family history. $17.4 \%, 61.8 \%$ and $20.8 \%$ patients have diabetes duration of $<5$ yrs., $5-10$ yrs. and $>10$ yrs. respectively. 33\% patients were on irregular treatment. $16.6 \%$ patients were hypertensive, $63.6 \%$ patients were overweight $\left(25-29.9 \mathrm{~kg} / \mathrm{m}^{2}\right)$ and $5.2 \%$ patients were obese $\left(>30 \mathrm{~kg} / \mathrm{m}^{2}\right) . \mathrm{In}$ present study, $59.56 \%$ male patients have waist circumference (WC) $\geq 90 \mathrm{~cm}$ and $60.98 \%$ female patients have WC $\geq 80 \mathrm{~cm}$. $25.60 \%$ patients have hypertriglyceridaemia and $18 \%$ patients have hypercholesterolaemia. $68.8 \%$ patients have poor glycaemic control.

\section{CONCLUSION}

The present study revealed that poor glycaemic control, irregular medication intake, obesity, dyslipidaemia and hypertension were prevalent in T2DM patients. Hence, the overall risk profile in patients from rural Vindhya region was very poor and needs improvement. These data can support health professional's actions to effectively maintain and provide a more comprehensive approach to management of T2DM.

\section{KEYWORDS}

Rural, Clinical Profile, Socio-Demographic Profile, Type 2 Diabetes Mellitus.

HOW TO CITE THIS ARTICLE: Baghel PK, Singh K, Singh UP. Clinical and Sociodemographic profile of type 2 diabetes mellitus in rural population of Vindhya region. J. Evolution Med. Dent. Sci. 2017;6(94):6820-6823, DOI: 10.14260/jemds/2017/1477

\section{BACKGROUND \\ Diabetes mellitus refers to a group of common metabolic} disorders that share the phenotype of hyperglycaemia with disturbance of carbohydrate, fat and protein metabolism resulting from defects in insulin secretion, insulin action or both. Several distinct types of DM are caused by a complex interaction of genetic and environmental factors. Depending on the aetiology of the DM, factors contributing to hyperglycaemia include reduced insulin secretion, decreased glucose utilisation and increased glucose production. ${ }^{1}$

DM is accepted as a worldwide epidemic with an estimated increase in prevalence from $2.8 \%$ in 2000

'Financial or Other Competing Interest': None.

Submission 26-10-2017, Peer Review 25-11-2017,

Acceptance 1-12-2017, Published 18-12-2017.

Corresponding Author:

Dr. Keshav Singh,

Assistant Professor,

Department of Medicine,

S. S. Medical College and S. G. M Hospital,

Rewa (M. P.).

E-mail: keshavsingh19@yahoo.com

DOI: $10.14260 /$ jemds $/ 2017 / 1477$

to $4.4 \%$ by $2030 .{ }^{2}$ It has been estimated that the global burden of DM for 2015 was 415 million people, which is projected to increase to 642 million in 2040. In 2015 number of men and women with diabetes was 215.2 million and 199.5 million, and by 2040 it will be 328.4 million and 313.3 million. In 2015 number of diabetics in urban and rural area was 269.7 million and 145.1 million and by 2040 it will be 477.9 million and 163.9 million. In 2015 one in 11 adults had diabetes and by 2040 one in 10 adults will have diabetes. ${ }^{3}$ The Indian Council of Medical Research India Diabetes Study (ICMR-INDIAB study) showed that India had 62.4 million people with diabetes in 2011. These numbers are projected to increase to 101.2 million by 2030.4 The prevalence of T2DM is $11 \%$ in urban areas, while it is $3 \%-9 \%$ in rural areas. 5 The prevalence of diabetes and its complications is now rapidly increasing in India among the poor in the urban slum dwellers, the middle class and even in the rural areas. This is due to changes in lifestyle and dietary habits associated with urbanisation and globalisation.

Unfortunately, the vast majority of population $(70 \%)$ in India live in rural areas. Screening for diabetes is seldom done in rural areas, resulting in a much greater burden of undiagnosed diabetics in rural areas. Most of these cases are 
type 2 diabetics. The earlier a person is diagnosed and management initiated, the better the chances of preventing harmful and costly complications.

\section{MATERIALS AND METHODS}

The present observational study was carried out in patients from rural areas attending Medicine Outpatient Department (MOPD) and those admitted in Department of Medicine, S.S. Medical College and associated S.G.M. Hospital, Rewa (M.P.) from 01st April 2016 to 31st July 2017. A total of 500 T2DM patients from rural population of Vindhya region were included in the study.

\section{Inclusion Criteria}

1. Type 2 diabetic patients living in rural area.

2. Age $>30$ years.

3. Giving consent for study.

\section{Exclusion Criteria}

1. Type 1 diabetic patients.

2. Diabetic, but belong to urban area.

3. Not giving consent.

Diabetes was defined by American Diabetes Association (ADA) 2011 criteria- Plasma fasting blood glucose $\geq 126$ $\mathrm{mg} / \mathrm{dL}$ or 2 -hour plasma post-glucose value $\geq 200 \mathrm{mg} / \mathrm{dL}$ or patients with classical symptoms of hyperglycaemia or hyperglycaemic crisis plus random blood glucose concentration $\geq 200 \mathrm{mg} / \mathrm{dL}$ ( $\geq 11.1 \mathrm{mmol} / \mathrm{L})$ or $\mathrm{HbA} 1 \mathrm{c}>$ $6.5 \%{ }^{6}$ Hypertension was diagnosed according to JNC-7 criteria, those with systolic blood pressure $>140 \mathrm{mmHg}$ and diastolic blood pressure $>90 \mathrm{mmHg}$ or who were taking antihypertensive medication were considered to have hypertension. ${ }^{7}$ Blood sample for lipid profile was taken after an overnight fast. Dyslipidaemia was defined if patient had total cholesterol $>200 \mathrm{mg} / \mathrm{dL}$, serum triglyceride $>150$ $\mathrm{mg} / \mathrm{dL}$, serum HDL $<40 \mathrm{mg} / \mathrm{dL}$ in males, $<50 \mathrm{mg} / \mathrm{dL}$ in female and serum LDL $>100 \mathrm{mg} / \mathrm{dL}^{8}$

The patients were included in the study after written and informed consent. Descriptive data like age, name, gender, religion, educational status, personal history, medical and medication history were taken after interviewing the patients. Patient's history and details were recorded on predesigned proforma. They underwent a thorough physical examination which included weight, height, waist circumference and Body Mass Index (BMI) which were calculated. Waist circumference was measured using a nonstretchable tape in horizontal position just above iliac crest. Data were completed by consulting medical reports of patients.

Data was at first arranged in Microsoft Excel 2016 worksheet, developed by Microsoft, Redmond, Washington. Data is expressed as mean \pm standard deviation for continuously distributed variables and in absolute numbers and percentages for the discrete variables.

\section{RESULTS}

Out of the 500 patients studied, 277 (55.4\%) were males and 223 (44.6\%) were females. Most of the patients 303 (66.6\%) were in the age group of $41-60$ years with mean age of 57 yrs. In our study, $56 \%$ patients were illiterate. In our study $71.8 \%$ patients were addicted to tobacco chewing, $28 \%$ tobacco smoking, $11.2 \%$ alcohol and $9.4 \%$ patients were addicted to both tobacco and alcohol.

In our study $37.4 \%$ patients have positive family history; $17.4 \%, 61.8 \%$ and $20.8 \%$ patients have diabetes duration of $<$ 5 yrs., 5 - 10 yrs. and > 10 yrs. respectively.

Out of 500 patients, $66.8 \%$ patients were on oral hypoglycaemic agents (OHA), 16.4\% were on insulin, $3 \%$ patients were treated with a combination of oral hypoglycaemic agents and insulin and $13.8 \%$ patients were not taking any type of treatment. $33 \%$ patients were on irregular treatment.

\begin{tabular}{|c|c|c|c|}
\hline Variable & Category & $\begin{array}{c}\text { No. of } \\
\text { Patients }\end{array}$ & Percentage \\
\hline \multirow{2}{*}{ Gender } & Male & 277 & $55.4 \%$ \\
\hline & Female & 223 & $44.6 \%$ \\
\hline \multirow{5}{*}{$\begin{array}{l}\text { Age Group } \\
\text { (Years) }\end{array}$} & $31-40$ & 30 & $6 \%$ \\
\hline & $41-50$ & 150 & $30 \%$ \\
\hline & $51-60$ & 153 & $30.6 \%$ \\
\hline & $61-70$ & 90 & $18.8 \%$ \\
\hline & $>70$ & 73 & $14.6 \%$ \\
\hline \multirow{2}{*}{$\begin{array}{c}\text { Educational } \\
\text { Status }\end{array}$} & Illiterate & 280 & $56 \%$ \\
\hline & Literate & 220 & $44 \%$ \\
\hline \multirow{4}{*}{ Addiction } & $\begin{array}{l}\text { Tobacco } \\
\text { chewing }\end{array}$ & 359 & $71.8 \%$ \\
\hline & $\begin{array}{l}\text { Tobacco } \\
\text { smoking }\end{array}$ & 140 & $28 \%$ \\
\hline & Alcohol & 56 & $11.2 \%$ \\
\hline & $\begin{array}{c}\text { Tobacco + } \\
\text { Alcohol }\end{array}$ & 47 & $9.4 \%$ \\
\hline \multirow{2}{*}{$\begin{array}{l}\text { Family } \\
\text { History }\end{array}$} & Present & 187 & $37.4 \%$ \\
\hline & Absent & 313 & $62.6 \%$ \\
\hline \multirow[b]{2}{*}{ Diet } & Vegetarian & 427 & $85.4 \%$ \\
\hline & $\begin{array}{c}\text { Non- } \\
\text { Vegetarian }\end{array}$ & 73 & $14.6 \%$ \\
\hline \multirow{3}{*}{$\begin{array}{c}\text { Duration of } \\
\text { Diabetes }\end{array}$} & $<5$ years & 87 & $17.4 \%$ \\
\hline & 5-10 years & 309 & $61.8 \%$ \\
\hline & $>10$ years & 104 & $20.8 \%$ \\
\hline \multirow{4}{*}{$\begin{array}{c}\text { Type of } \\
\text { Treatment }\end{array}$} & OHA & 334 & $66.8 \%$ \\
\hline & Insulin & 82 & $16.4 \%$ \\
\hline & $\mathrm{OHA}+$ Insulin & 15 & $3 \%$ \\
\hline & No treatment & 69 & $13.8 \%$ \\
\hline \multirow{2}{*}{$\begin{array}{l}\text { Regularity of } \\
\text { Treatment }\end{array}$} & Regular & 335 & $67 \%$ \\
\hline & Irregular & 165 & $33 \%$ \\
\hline Table 1 & mographic $P$ & file of $P$ & ients \\
\hline
\end{tabular}

In our study, $16.6 \%$ patients were hypertensives.

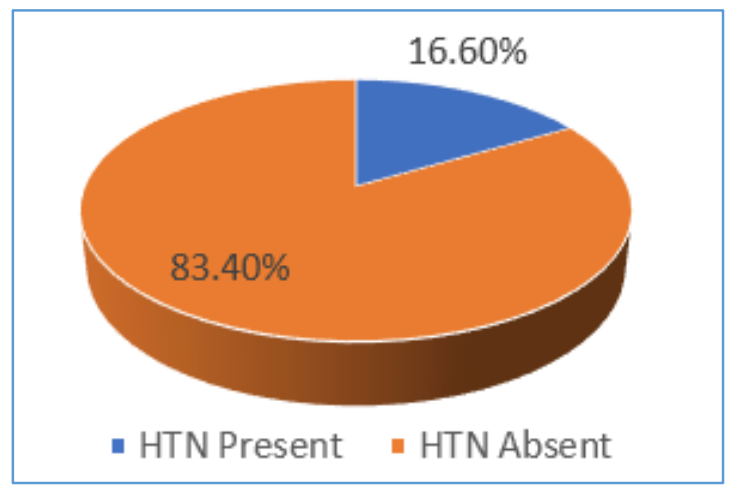

Figure 1. Prevalence of Hypertension 
In our study, 63.6\% patients were overweight (25 - 29.9 $\left.\mathrm{kg} / \mathrm{m}^{2}\right)$ and $5.2 \%$ patients were obese $\left(>30 \mathrm{~kg} / \mathrm{m}^{2}\right)$.

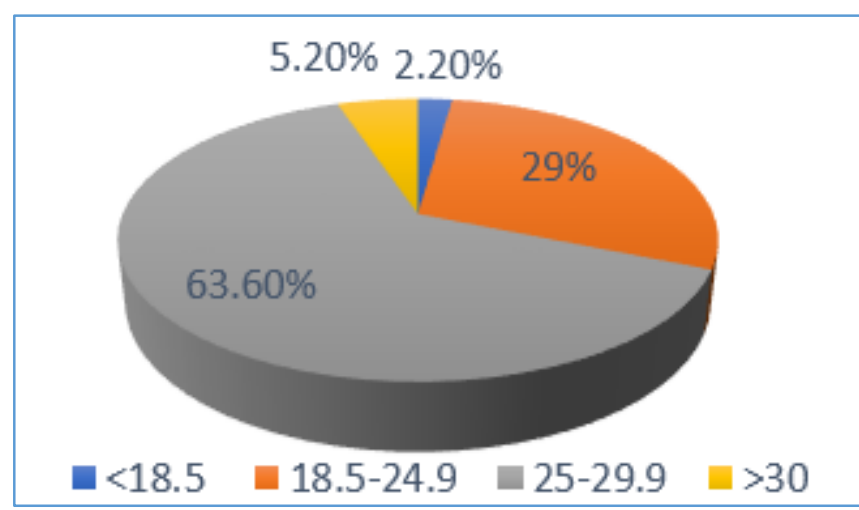

Figure 2. Body Mass Index Distribution

In our study, $59.56 \%$ male patients have $\mathrm{WC} \geq 90 \mathrm{~cm}$ and $60.98 \%$ female patients have $\mathrm{WC} \geq 80 \mathrm{~cm} ; 25.60 \%$ patients have hypertriglyceridaemia and $18 \%$ patients have hypercholesterolaemia.

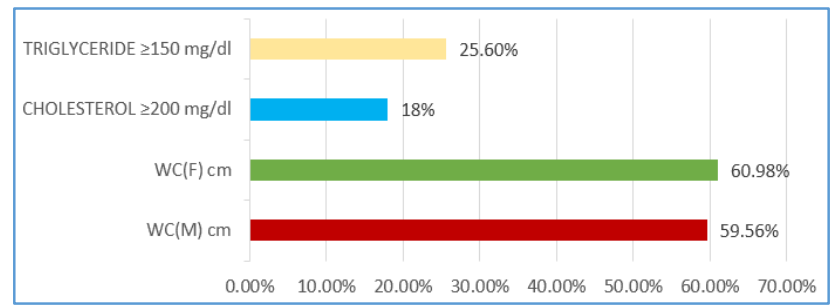

Figure 3. Distribution of Patients according to Lipid Profile and Waist Circumference

In our study, $31.2 \%$ patients have $\mathrm{FBS} \leq 140 \mathrm{mg} / \mathrm{dL}$ and $68.8 \%$ patients have $\mathrm{FBS}>140 \mathrm{mg} / \mathrm{dL}$.

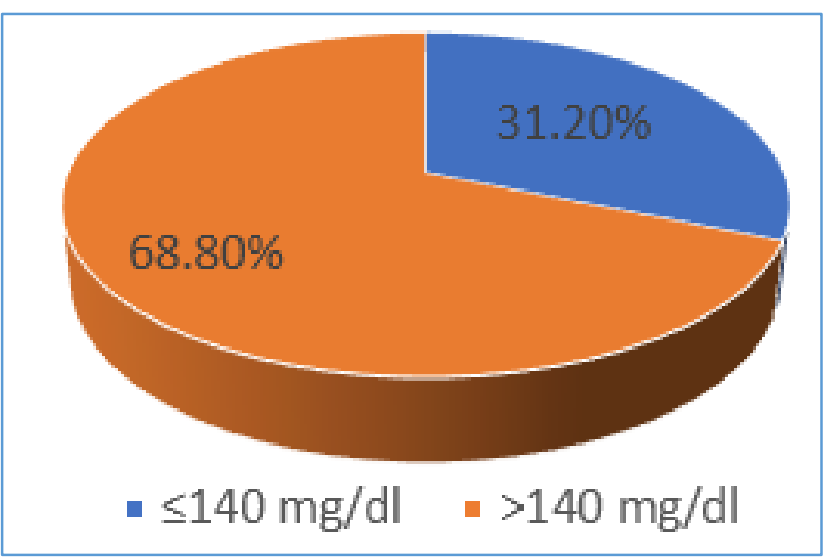

Figure 4. Distribution of Patients according to Glycaemic Control

\section{DISCUSSION}

In our study, 277 (55.4\%) were males and 223 (44.6\%) were females. Thakkar B et al ${ }^{9}$ reported prevalence of DM was $58 \%$ in males and $42 \%$ in females. Santosh YL et al ${ }^{10}$ reported prevalence in males of $58.23 \%$ and that in females of $41.76 \%$. In our study, $303(66.6 \%)$ patients were in the age group of 41 - 60 years with mean age of 57 yrs. Shah A et al ${ }^{11}$ found that prevalence of DM was highest in the age group of 40 - 60
(56.12\%) years followed by $60-80$ (32.31\%) years' age group. Manish Srishat ${ }^{12}$ reported mean age of 56 years.

In our study $71.8 \%$ patients were addicted to tobacco chewing, $28 \%$ were addicted to tobacco smoking, $11.2 \%$ were addicted to alcohol and $9.4 \%$ patients were addicted to both tobacco and alcohol. According to a previous study done by Bhalerao SD et al, ${ }^{13}$ smoking was seen in $30.2 \%$ and alcohol consumption was found in $26.4 \%$ cases of T2DM.

In our study, 187 (37.4\%) patients have positive family history. Abdollahi et al ${ }^{14}$ who observed 152 newly detected diabetic patients and reported family history in 63 patients (41.4\%). Ranganayakulu $\mathrm{K}$ et al ${ }^{15}$ reported that positive family history was present in $1 / 3$ of newly detected diabetics. According to all these studies, there was strong relationship between family history and diabetes mellitus. Relationship of family history with type 2 diabetes mellitus is due to strong genetic component.

In our study, $16.6 \%$ patients were hypertensives. Nanda $\mathrm{KC}$ et al ${ }^{16}$ observed that $21.7 \%$ patients had hypertension. Harzallah $\mathrm{F}$ et al ${ }^{17}$ reported prevalence of hypertension to be $22 \%$ among newly detected diabetic patients.

In our study, 63.6\% patients were overweight (25 - 29.9 $\mathrm{kg} / \mathrm{m}^{2}$ ) and $5.2 \%$ patients were obese (> $\left.30 \mathrm{~kg} / \mathrm{m}^{2}\right)$. Krahulec B et al 18 reported an average BMI of $25-30 \mathrm{~kg} / \mathrm{m}^{2}$ in $43.9 \%$. Ganesh A et al $^{19}$ found that on the basis of BMI $5 \%$ were obese, $49 \%$ were overweight and $46 \%$ patients were within normal range. Baijayanti Baur et al ${ }^{20}$ concluded that Diabetes was more (63.6\%) among patients who had BMI (Body Mass Index) of $25 \mathrm{~kg} / \mathrm{m}^{2}$ or more.

In our study, $59.56 \%$ male patients have $\mathrm{WC} \geq 90 \mathrm{~cm}$ and $60.98 \%$ female patients have $\mathrm{WC} \geq 80 \mathrm{~cm}$. Borah $\mathrm{M}$ et $\mathrm{al}^{21}$ observed that central obesity (waist circumference; men $\geq 90$ and women $\geq 80 \mathrm{~cm}$ ) was $58 \%$ in diabetic population.

In our study, $25.60 \%$ patients have hypertriglyceridaemia and $18 \%$ patients have hypercholesterolaemia. Mandal $\mathrm{M}$ et al22 found hypercholesterolaemia and hypertriglyceridaemia in $34.29 \%$ and $25.71 \%$ patients respectively.

Shukla $\mathrm{V}$ et $\mathrm{al}^{23}$ found that $30 \%$ patients had a serum triglyceride level of more than $150 \mathrm{mg} \%$ and $20 \%$ patients had total serum cholesterol of more than $200 \mathrm{mg} \%$. Bali K et al24 found that $36.5 \%$ patients have hypercholesterolaemia and $57.2 \%$ patients have hypertriglyceridaemia.

\section{CONCLUSION}

Our study was an attempt to highlight the scenario of T2DM in rural areas of Vindhya region. An insight into this region would hence prove valuable in formulating preventive and treatment policies specific for this region. The present study revealed that obesity, dyslipidaemia, family history of diabetes, uncontrolled glycaemic status, hypertension, nonadherence to treatment and addiction were highly prevalent in T2DM subjects. Hence, the overall risk profile was very poor. Thus, more thought should be given to the importance of multiprofessional team education in diabetic patient care, enlightening them about nature and progression of the disease and possible complications. They may benefit from periodical health promotion and education programs in the area of diet management, self-care and adherence to treatment. Clinicians involved with managing cases of diabetes should give sufficient importance and information 
regarding lifestyle modifications, encouraging diet control and exercise pattern among their patients to achieve better control of diabetes.

\section{REFERENCES}

[1] Classification of diabetes mellitus and other categories of glucose intolerance. In: Alberti K, Zimmet P, De Fronzo R, (eds). International Textbook of Diabetes Mellitus. Chichester: John Willey and Sons Ltd, 1997:923.

[2] Wild S, Roglic G, Green A, et al. Global prevalence of diabetes mellitus: estimates for the year 2000 and projections for 2030. Diabetes Care 2004;27(5):104753.

[3] International Diabetes Federation. IDF Diabetes Atlas, 7th edn. Brussels, Belgium: International Diabetes Federation. 2015;7:55-63.

[4] Anjana RM, Pradeepa R, Deepa M, et al. Prevalence of diabetes and prediabetes (impaired fasting glucose and/or impaired glucose tolerance) in urban and rural India: phase I results of the Indian council of medical research India diabetes (ICMR-INDIAB) study. Diabetologia 2011;54(12):3022-7.

[5] Park K. Park's textbook of preventive and social medicine. 20th edn. Jabalpur India: M/s Banarsidas Bhanot, 2009.

[6] American Diabetes Association. Diagnosis and classification of diabetes mellitus. Diabetes Care 2011;34(Suppl 1):S62-9.

[7] Chobanian AV, Bakris GL, Black HR, et al. The seventh report of the joint national committee on prevention, detection, evaluation and treatment of high blood pressure: the JNC 7 report. JAMA 2003;289(19):256072.

[8] Expert Panel on Detection, Evaluation, and Treatment of High Blood Cholesterol in Adults. Executive summary of the third report of the national cholesterol education program (NCEP) expert panel on detection, evaluation, and treatment of high blood cholesterol in adults (adult treatment panel III). JAMA 2001;285(19):2486-97.

[9] Thakkar B, Arora K, Vekariya R, et al. Prevalence of microalbuminuria in newly diagnosed type 2 diabetes mellitus. Natl J Integr Res Med 2011;2(4):22-5.

[10] Santhosh YL, Vasanth K, Ramanth KV. Prevalence of type 2 diabetes mellitus in rural tertiary care south Indian hospital. Der Pharmacia Sinica 2011;2(2):74-8.

[11] Shah A, Afzal M. Prevalence of diabetes and hypertension and association with various risk factors among different Muslim populations of Manipur, India. J Diabetes Metab Disord 2013;12:52.
[12] Srishat M. Complications at diagnosis of NIDDM. Research Society for the Study of Diabetes in India. (RSSDI) 1997.

[13] Bhalerao SD, Somannavar M, Vernekar SS, et al. Risk factors for type 2 diabetes mellitus in rural population of north Karnataka: a community-based crosssectional study. Int J Pharm Med \& Bio Sc 2014;3(1):114.

[14] Abdollahi A, Malekmadani M, Mansoori MR, et al. Prevalence of diabetic retinopathy in patients with newly diagnosed type II diabetes mellitus. Acta Medica Iranica 2006;44(6):415-9.

[15] Ranganayakulu K, Pruthvi B, Subramanian R, et al. Clinical profile and complications in newly detected type-2 diabetics (Age group 20-60 years). APICON 2008; www.japi .org/July 2008/hae_med_ onc_dia,neurology:html.

[16] Nanda KC, Tripathy D, Mohapatra SK, et al. A study of diabetic hypertensives. J Ass Phys Ind 1992;40(12):879.

[17] Harzallah F, Ncibi N, Alberti $\mathrm{H}$, et al. Clinical and metabolic characteristics of newly diagnosed diabetic patients: experience of a university hospital in Tunis. Diabetes Metab 2006;32(6):632-5.

[18] Krahulec B, Vozar J. Incidence of risk factors and vascular complications in patients with newly diagnosed type 2 diabetes mellitus. Vnitr Lek 2002;48(11):1031-8.

[19] Ganesh A, Borkar M, Sikariya K, et al. Clinical profile of type 2 diabetes. WJPMR 2017;3(6):294-8.

[20] Baur, Baijayanti, Manna N, et al. An epidemiological study on risk factors of diabetes mellitus among the patients attending a tertiary care hospital of West Bengal, India. Global Journal of Medicine and Public Health 2013;2(4):1-7.

[21] Borah M, Goswami RK. Sociodemographic and clinical characteristics of a diabetic population at a tertiary care center in Assam, India. J Soc Health Diabetes 2017;5(1):37-42.

[22] Mandal M, Kumari R, Mukherjee A. Prevalence of dyslipidemia in patients with type 2 diabetes mellitus: a hospital based study in Kishanganj, India. Int J Res Med Sci 2015;3(12):3691-7.

[23] Shukla V, Karoli R, Chandra A. A study of newly diagnosed type 2 diabetes mellitus patients from rural areas. JAPI 2014;62(8):682-4.

[24] Bali K, Vij AS. Pattern of dyslipidemia in type 2 diabetes mellitus in Punjab. Int J Res Med Sci 2016;4(3):809-12. 